\title{
MANAGEMENT INFORMATION SYSTEMS ISSUES: CO-CITATION ANALYSIS OF JOURNAL ARTICLES
}

\author{
Wen-Lung Shiau \\ Ming Chuan University \\ 5 De Ming Rd., Gui Shan District, Taoyuan County 333, Taiwan \\ mac@mail.mcu.edu.tw \\ Shu-Yi Chen \\ Ming Chuan University \\ 5 De Ming Rd., Gui Shan District, Taoyuan County 333, Taiwan \\ maxchen@mail.mcu.edu.tw \\ Yu-Cheng Tsai \\ Ming Chuan University \\ 5 De Ming Rd., Gui Shan District, Taoyuan County 333, Taiwan \\ osiris_sky@hotmail.com
}

\section{ABSTRACT}

This study aimed to analyze and identify key issues being studied in leading Management Information Systems (MIS) journals collected in an ISI database. With the help of co-citation analysis and factor analysis, thirteen core issues were identified, including: (1) Technology Acceptance; (2) Information Technology (IT), Organization Performance, and Competitive Advantage; (3) IT and Organizational Structure; (4) Case Study and Methodology Issues; (5) Trust Issues in IT; (6) Knowledge Management; (7) Measurement Issues in MIS study; (8) Diffusion of Innovation; (9) Success Factors of IT; (10) Research Modeling and Approach; (11) Theory, Research and Practice; (12) MIS as an academic discipline; and (13) Enterprise Information Systems. These results can help MIS researchers and practitioners gain a better awareness of core and significant issues being studied in the field.

Keywords: MIS, Management Information Systems, Key Issues, Co-Citation 


\section{INTRODUCTION}

Information technology (IT) has changed every aspect of life, from an individual level, to a societal level, and in fact for the whole world. Advanced technology and services, such as open source software and cloud computing, bring new possibility to the IT industry, and certainly create impact on our lives. Since the 1980s, the Society for Information Management (SIM) has surveyed practitioners and researchers in IT and Information Systems (IS) fields, so as to understand the most significant issues in the field, the ranking of such issues, and to elucidate agreement regarding issues/ranking among participants ${ }^{1}$. This periodic survey and the results have become an important reference to MIS researchers everywhere and are consulted when considering investigations in the field, or for a comparison to local issues being considered.

As the world relies increasingly on various information systems and technology, key MIS issues have also become more vital when businesses are trying to leverage IT for a business advantage. Likewise, researchers need to consider which issues to select for research and which are more meaningful to the field. However, as the trends are continuously changing, core issues and ranking need to be updated regularly to stay current. Therefore, this study addresses this need by answering the following research questions:

1. What major papers are co-cited in leading academic journals?

2. What are key MIS issues in leading academic journals?

To determine core issues that are being addressed in academia, one must go through a large number of journals to extract information on what topics are most significant. With the sheer volumes of articles involved, the task becomes non-trivial; great effort and time are needed. The approach taken by this study is, after collecting and summarizing articles from leading journals, to analyze them with co-citation analysis to automatically identify the central issues being looked at among researchers. The goal of this study, hence, is to summarize key topics covered by researchers as presented in MIS journals in a timely manner. The journals included in this study are the European Journal of Information Systems (EJIS), Information Systems Journal (ISJ), Information Systems Research (ISR), Journal of Information Technology (JIT), Journal of Management Information Systems (JMIS), Journal of Strategic Information Systems (JSIS), Journal of the Association for Information Systems (JAIS), and MIS Quarterly (MISQ). Additional details on the summarizing process and analysis will be presented in later sections. 


\section{LITERATURE REVIEW}

\subsection{MIS Key Issues}

Despite the advances in IT, the story does not always end happily when companies adopt new information technology. This results in a high interest in the factors affecting successful introduction of IT. Moreover, companies large and small are interested in learning about current topics in technology and related managerial issues to better leverage IT in an organization ${ }^{2}$. Key issues in MIS, therefore, appeal to a wide audience and related study began to emerge during the 1980s. Ball and Harris ${ }^{3}$ were among the first to conduct a survey on this topic. They asked 417 members of SIM to rank 18 MIS-related issues. Dickson et al. ${ }^{1}$, based on the results of Ball and Harris, conducted a four-round Delphi survey on 52 SIM members to determine the most significant issues being looked at over the previous 5 to 10 years. Niederman et al. ${ }^{4}$ also surveyed 241 SIM members with a three-round Delphi approach. The issues and ranking were provided along with the trend analysis on the issues. Two trends were proposed as likely in the 1990s: (1) Technology infrastructure related topics were more significant; and (2) Efficiency in organizations would find favor again among business.

Palvia et al. ${ }^{5}$ took a different approach in developing key issues by collecting and summarizing articles from seven leading research journals. A total of 630 articles from January 1989 to June 1993 were analyzed with the following findings: (1) A new issue (Expert Systems) was found in numerous articles, though it was not in the list of Niederman et al. ${ }^{4}$; and (2) Executive/Decision Support Systems, Software Development, and Telecommunications Systems appeared in most articles, so they were ranked the highest in the list. Luftman and Kempaiah ${ }^{6}$ did a survey with 112 organization members of SIM and asked participants to rank 38 managerial and 65 technology issues. A similar survey was conducted and reported by Luftman and Ben-Zvi in a 2010 issue of MIS Quarterly Executive. This time 172 SIM members participated to rank 39 management and 52 technology issues. As discussed, survey was the main approach to collect and rank key issues. Palvia et al. ${ }^{5}$, however, tried to gather conclusions from analyzing academic journals. Issues found in this way were thus more research-oriented, and also indicated possible direction of trends, as research journals sometimes covers topics before they are actually applied in practice. Hence, identifying the issues that are being covered in journals can help researchers, and practitioners alike, to be aware of new topics and how to allocate resources for future study. 


\subsection{Co-citation Analysis}

Small $^{8}$ was one of the first, after Kessler's ${ }^{9}$ bibliographic coupling, to propose the idea of co-citation. This approach aims to collect core knowledge structure embedded in research papers by looking at how the same pairs of articles are cited by other articles. Scholars generally agree upon the benefits of co-citation analysis as it is able to reveal the knowledge structure of a research field, along with trend hidden in the published research $^{10,11}$. Several levels of co-citation analysis exist and the most often are seen as document, author, and journal co-citation analysis. Small ${ }^{8}$ took a document co-citation approach to study papers in particle physics and found that co-citation should be interpreted with both subject similarity and association of ideas. White and Griffith ${ }^{12}$, based on the idea of Small ${ }^{8}$, suggested author co-citation analysis approach that analyzes how the same pairs of authors were cited together. $\mathrm{McCain}^{13}$ later proposed journal co-citation to study the structure of an academic field. Other researchers had done co-citation work with the Social Sciences Citation Index (SSCI) and Science Citation Index (SCI) from ISI, or similar indexes from other databases. Some of the studies tried to find a threshold of citation number to filter articles with higher contribution, and to find clusters of core issues with trend (for example, see Schildt et al. ${ }^{14}$, Tight ${ }^{15}$ ). With the assistance of factor analysis, co-citation analysis is able to help new researchers in a field to more quickly and qualitatively understand the knowledge context and important papers of the field ${ }^{16,17,18}$.

\section{METHODS}

The main methods used for analysis in this study originated from bibliometrics, which is "the application of mathematics and statistical methods to books and other media of communication" ${ }^{19}$. Among methods in bibliometrics, citation analysis analyzes relationships between citing and cited works ${ }^{20}$. Highly cited papers are generally regarded as significant in a related academic field. Although pioneers such as Price ${ }^{21}$ tried to use citation analysis to examine the internal structure of knowledge within a specific discipline, it was later found that co-citation analysis may be a better tool. Since the purpose of this study is to find core issues and knowledge in the MIS field, co-citation analysis was chosen as the primary analysis method.

Co-citation analysis calculates and analyzes the number of times that two articles are cited together by a third article, to show the relationship between the cited pair. For example, if paper A and B are both cited in a later paper I, A and B can be thought of as relating to each other in terms of subject matter. A co-citation index of 1 (one) then can be assigned to this 
pair $\mathrm{A}$ and $\mathrm{B}$. If $\mathrm{A}$ and $\mathrm{B}$ are also cited in paper II, their index becomes 2 (two). The larger the index number of a pair, the stronger the relationship between the pair. By comparing the cited paper pairs of source articles, an index can be created and analyzed, as shown in Figure 3-1.

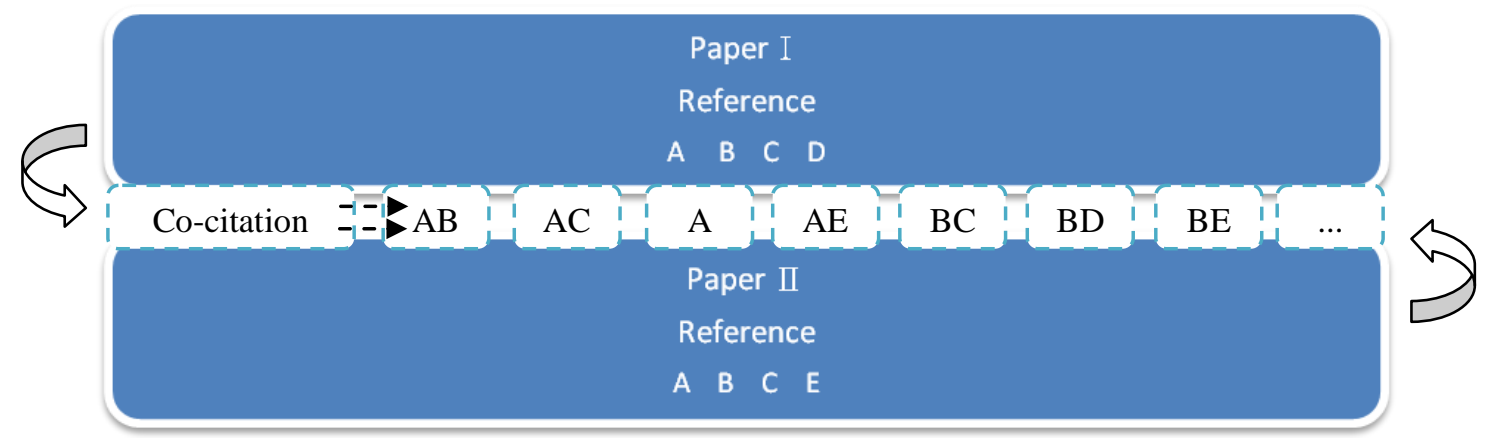

Figure 3-1. Co-citation relationship

With co-citation analysis, the hidden relationship between research papers can be found. Specifically, clusters formed by highly co-cited papers reveal the structure of the academic discipline, along with significant issues. Small and Griffith ${ }^{22}$ provided questions that could be answered by co-citation analysis, including: (1) What is the natural structure of science? (2) What is the relationship between the units of structure? (3) What causes the relationship? (4) How does the structure change over time?

Co-citation analysis, when combined with factor analysis, provides a way to reveal internal relationship among cited pairs of papers. Factor analysis is able to summarize and simplify data with fewer variables, so it is chosen in this study to examine the possible factors/issues behind observed clusters of papers. According to $\mathrm{McCain}^{23}$, factor loading greater than 0.7/-0.7 has a better interpreting power. This study, accordingly, adopted this criterion in examining factor loading.

The eight journals selected, namely EJIS, ISJ, ISR, JIT, JMIS, JSIS, JAIS, MISQ, are the "basket" leading journals ${ }^{24}$ from Senior Scholar Consortium of Association for Information Systems (AIS). The journals are recognized as top journals in MIS field, with variety in topics, methods and geography focus. These journals are good representation of the MIS discipline, so they present nice starting point for co-citation analysis. Papers from these eight journals during the period of 1996-2010 were selected as citing papers. However, for co-cited papers, only highly cited papers were chosen, as these papers may better represent shared concern and focus of a discipline. 


\section{RESULTS}

This section presents the results of analysis based on co-citation analysis and factor analysis.

\subsection{Co-citation Analysis}

As mentioned, articles from eight leading MIS journals were analyzed. The threshold of citation was set to 47; that is, to be included for later co-citation analysis, papers must be cited at least 47 times in those journals. A total of 118 papers were selected according to this criterion. Please see Table 4-1 for these highly co-cited papers.

Table 4-1. Highly co-cited papers in eight leading MIS journals

\begin{tabular}{|c|c|c|}
\hline No & Author(Year) & Journal \\
\hline 1 & Davis(1989) & MIS Quarterly \\
\hline 2 & Fornell and Larcker(1981) & Journal of Marketing Research \\
\hline 3 & Eisenhardt(1989) & Academy Of Management Review \\
\hline 4 & Davis et al.(1989) & Management Science \\
\hline 5 & DeLoneabd McLean (1992) & Information Systems Research \\
\hline 6 & Klein and Myers(1999) & MIS Quarterly \\
\hline 7 & Venkatesh et al.(2003) & MIS Quarterly \\
\hline 8 & Moore and Benbasat(1991) & Information Systems Research \\
\hline 9 & Desanctis and Poole(1994) & Organization Science \\
\hline 10 & Malone et al.(1987) & Communications Of The ACM \\
\hline 11 & Orlikowski and Baroudi(1991) & Information Systems Research \\
\hline 12 & Taylor and Todd(1995) & Information Systems Research \\
\hline 13 & Orlikowski and Iacono(2001) & Information Systems Research \\
\hline 14 & Benbasat et al.(1987) & MIS Quarterly \\
\hline 15 & Walsham(1995) & European Journal of Information Systems \\
\hline 16 & Barney(1991) & Journal of Management \\
\hline 17 & Markus et al(1983) & Communications of the ACM \\
\hline 18 & Venkatesh and Davis(2000) & Management science \\
\hline 19 & Orlikowski(1992) & Organization Science \\
\hline 20 & Cohen and Levinthal(1990) & Administrative Science Quarterly \\
\hline 21 & Orlikowski(1993) & MIS Quarterly \\
\hline 22 & Daft and Lengel(1986) & Management Science \\
\hline 23 & Podsakoff et al.(2003) & Journal of applied psychology \\
\hline 24 & Bharadwaj(2000) & MIS Quarterly \\
\hline 25 & Porter and Millar(1985) & Harvard business review \\
\hline 26 & Anderson et al.(1988) & Psychological Bulletin \\
\hline 27 & Goodhue and Thompson(1995) & MIS Quarterly \\
\hline 28 & Hevner et al.(2004) & MIS Quarterly \\
\hline 29 & Ajzen(1991) & Organizational behavior and human decision processes \\
\hline 30 & Gefen et al.(2003) & MIS Quarterly \\
\hline 31 & Mata et al.(1995) & MIS Quarterly \\
\hline 32 & Alavi and Leidner(2001) & MIS Quarterly \\
\hline 33 & Karahanna et al.(1999) & MIS Quarterly \\
\hline 34 & Mayer et al.(1995) & The Academy of Management Review \\
\hline 35 & Straub(1989) & MIS Quarterly \\
\hline 36 & Baron and Kenny(1986) & Journal of Personality and Social Psychology \\
\hline 37 & Teece et al.(1997) & Strategic management journal \\
\hline
\end{tabular}


Table 4-1. Highly co-cited papers in eight leading MIS journals (Cont.)

\begin{tabular}{|c|c|c|}
\hline No & Author(Year) & Journal \\
\hline 38 & Orlikowski(2000) & Organization science \\
\hline 39 & Markus and Robey(1988) & Management Science \\
\hline 40 & Nonaka(1994) & Organization Science \\
\hline 41 & Compeau and Higgins(1995) & MIS Quarterly \\
\hline 42 & Chin and Newsted(2003) & Information systems research \\
\hline 43 & Benbasat and Zmud(2003) & MIS Quarterly \\
\hline 44 & Cooper and Zmud(1990) & Management Science \\
\hline 45 & DeLone and McLean(2003) & Journal of management information systems \\
\hline 46 & Barua et a.(1995) & Information Systems Research \\
\hline 47 & McKnight et al.(2002) & Information Systems Research \\
\hline 48 & Sambamurthy et al.(2003) & MIS Quarterly \\
\hline 49 & Orlikowski(1996) & Information Systems Research \\
\hline 50 & Barclay et al(1995) & Technology studies \\
\hline 51 & Ross et al.(1996) & Sloan management review \\
\hline 52 & Brynjolfsson and Hitt(1996) & Management science \\
\hline 53 & Podsakoff and Organ(1986) & Journal of Management \\
\hline 54 & Venkatesh(2000) & Information Systems Research \\
\hline 55 & Venkatesh and Morris(2000) & MIS Quarterly \\
\hline 56 & Swanson(1994) & Management Science \\
\hline 57 & Armstrong and Overton(1977) & Journal of Marketing Research \\
\hline 58 & Davenport(1998) & Harvard business review \\
\hline 59 & Agarwal and Karahanna(2000) & MIS Quarterly \\
\hline 60 & Churchill(1979) & Journal of Marketing Research \\
\hline 61 & Grant(1996) & Strategic management journal \\
\hline 62 & Robey et al.(2002) & Journal of management information systems \\
\hline 63 & Brown and Duguid(1991) & Organization Science \\
\hline 64 & Orlikowski and Robey(1991) & Information systems research \\
\hline 65 & Clemons et al.(1993) & Journal of Management Information Systems \\
\hline 66 & DiMaggio and Powell(1983) & American Sociological Review \\
\hline 67 & Ives et al.(1983) & Communications of the ACM \\
\hline 68 & $\begin{array}{l}\text { Henderson and } \\
\text { Venkatraman(1993) }\end{array}$ & IBM Systems Journal \\
\hline 69 & Wernerfelt(1984) & Strategic Management Journal \\
\hline 70 & Jarvenpaa and Leidner(1999) & Organization science \\
\hline 71 & Benbasat and Zmud(1999) & MIS Quarterly \\
\hline 72 & Mcknight et al.(1998) & Academy of management review \\
\hline 73 & Gefen and Straub(1997) & MIS Quarterly \\
\hline 74 & Mathieson(1991) & Information Systems Research \\
\hline 75 & Mukhopadhyay et al.(1995) & MIS Quarterly \\
\hline 76 & Iacovou et al.(1995) & MIS Quarterly \\
\hline 77 & Hirschheim and Klein(1989) & Communications of the ACM \\
\hline 78 & Eisenhardt and Martin(2000) & Strategic management journal \\
\hline 79 & Lyytinen(1987) & Oxford surveys in evolutionary biology \\
\hline 80 & Nunamaker et al.(1991) & Communications of the ACM \\
\hline 81 & Pavlou and Gefen(2004) & Information Systems Research \\
\hline 82 & Majchrzak et al.(2000) & MIS Quarterly \\
\hline 83 & Powell and DentMicallef(1997) & Strategic management journal \\
\hline 84 & $\begin{array}{l}\text { Armstrong and } \\
\text { Sambamurthy(1977) }\end{array}$ & Information Systems Research \\
\hline 85 & Adams et al.(1992) & MIS Quarterly \\
\hline 86 & Bailey and Pearson(1983) & Management Science \\
\hline 87 & Melville et al.(2004) & MIS Quarterly \\
\hline 88 & Hartwick and Barki(1994) & Management Science \\
\hline
\end{tabular}


Table 4-1. Highly co-cited papers in eight leading MIS journals (Cont.)

\begin{tabular}{lll}
\hline No & Author(Year) & Journal \\
\hline $\mathbf{8 9}$ & Kogut and Zander(1992) & Organization Science \\
$\mathbf{9 0}$ & Attewell(1992) & Organization Science \\
$\mathbf{9 1}$ & Orlikowski and Gash(1994) & ACM Transactions on Information Systems \\
$\mathbf{9 2}$ & Curtis et al.(1988) & Communications of the ACM \\
$\mathbf{9 3}$ & Prahalad and Hamel(1990) & Harvard Business Review \\
$\mathbf{9 4}$ & Walsham(1995) & Information Systems Research \\
$\mathbf{9 5}$ & Lee(1989) & MIS Quarterly \\
$\mathbf{9 6}$ & Robey et al.(1999) & Information Systems Research \\
$\mathbf{9 7}$ & Fornell and Bookstein(1982) & Journal of Marketing Research \\
$\mathbf{9 8}$ & Gefen et al.(2000) & Communications of the Association for Information \\
$\mathbf{9 9}$ & Straub et al.(1995) & Systems \\
$\mathbf{1 0 0}$ & Bagozzi et al.(1991) & Management Science \\
$\mathbf{1 0 1}$ & DeSanctis and Gallupe(1987) & Administrative Science Quarterly \\
$\mathbf{1 0 2}$ & Ngwenyama and Lee(1997) & Management Science \\
$\mathbf{1 0 3}$ & Koufaris(2002) & MIS Quarterly \\
$\mathbf{1 0 4}$ & Ba and Pavlou(2002) & Information Systems Research \\
$\mathbf{1 0 5}$ & Carr(2003) & MIS Quarterly \\
$\mathbf{1 0 6}$ & Chin(1998) & Harvard business review \\
$\mathbf{1 0 7}$ & Tornatzky and Klein(1982) & MIS Quarterly \\
$\mathbf{1 0 8}$ & Weill(1992) & IEEE Transactions on Engineering Management \\
$\mathbf{1 0 9}$ & Lacity and Willcocks(1998) & Information Systems Research \\
$\mathbf{1 1 0}$ & Campbell and Fiske(1959) & MIS Quarterly \\
$\mathbf{1 1 1}$ & Earl(1993) & Psychological Bulletin \\
$\mathbf{1 1 2}$ & Barley(1986) & MIS Quarterly \\
$\mathbf{1 1 3}$ & Wade and Hulland(2004) & Administrative Science Quarterly \\
$\mathbf{1 1 4}$ & Jarvis et al.(2003) & MIS Quarterly \\
$\mathbf{1 1 5}$ & Grant(1996) & Journal of consumer research \\
$\mathbf{1 1 6}$ & Seddon(1997) & Organization science \\
$\mathbf{1 1 7}$ & Granovetter(1985) & Information Systems Research \\
$\mathbf{1 1 8}$ & Lee(1991) & The American Journal of Sociology \\
\hline & & Organization Science \\
\hline
\end{tabular}

A co-citation matrix of 118 by 118 was created to show the co-citation numbers between these paper pairs. The first row and column (headings) are the codes for papers, from 1 to 118, to be used in factor analysis. Each cell in the matrix indicates the number of co-citation by the two papers of the intercepting row and column headings. The matrix, hence, is a symmetric matrix, in addition to a square matrix. Moreover, the main diagonal cells are set to be the largest co-citation number of the corresponding paper ${ }^{25}$.

\subsection{Factor Analysis}

With the co-citation matrix, principle component analysis and varimax rotation were applied to perform factor analysis on selected papers ${ }^{18}$. With SPSS 19, 17 factors were found to have a combined $88.22 \%$ of variance explained. Among the 17 factors, 4 factors have few numbers of papers with diverse topics, so the 4 factors are not included in the discussion here. Please see Table 4-2 for the 13 factors, papers, and percentage of variance 
explained. Central concept within each concept was decided through content analysis of the abstracts. Those main concepts of the 13 factors are: (1) Technology Acceptance; (2) IT, Organization Performance, and Competitive Advantage; (3) IT and Organizational Structure; (4)Case Study and Methodology Issues; (5) Trust Issues in IT; (6) Knowledge Management; (7) Measurement Issues in MIS study; (8) Diffusion of Innovation; (9) Success Factors of IT; (10) Research Modeling and Approach; (11) Theory, Research and Practice; (12) MIS as an academic discipline; and (13) Enterprise Information Systems.

\section{DISCUSSION}

The main approach of this study was citation analysis, as highly-cited articles generally represent significant ideas, methods or progress in various research fields ${ }^{26}$. To better explore the structure of the MIS discipline, co-citation analysis was used to discover the hidden connections among research papers from leading MIS journals. Factor analysis was also done to find MIS key issues.

The results of factor analysis identified thirteen factors (key issues). The first factor was labeled "Technology Acceptance." Papers in this factor were mostly about TAM (Technology Acceptance Model), including the model's various applications and extensions (see Table 4-2, for example: Venkatesh and Davis ${ }^{27}$, Straub and Limayen ${ }^{28}$, Bailey and Pearson ${ }^{29}$, Mayer et al. ${ }^{30}$, Chin et al. ${ }^{31}$, DeSanctis and Poole ${ }^{32}$, Davis ${ }^{33}$, Karahanna et al. ${ }^{34}$, Venkatesh $^{35}$, Venkatesh et al. ${ }^{36}$ ). The second factor was "IT, Organization Performance, and Competitive Advantage," (see Table 4-2, for examples, Bharadwaj ${ }^{37}$, Carr ${ }^{38}$, Porter and Millar ${ }^{2}$, Barua et al. ${ }^{39}$, Orlikowski ${ }^{40}$, Grant $^{41}$, Markus ${ }^{42}$, Porter and Millar ${ }^{2}$, Carr $^{38}$ ).

The third factor was "IT and Organization Structure." The topic of this factor centered on the interaction between IT and organization (see Table 4-2, for examples, Orlikowski ${ }^{43}$, Robey and Boudreau ${ }^{44}$, and Orlikowski ${ }^{45}$ ). The fourth factor was, "Case Study and Methodology Issues (see Table 4-2, for examples, $\mathrm{Lee}^{46}$, Walsham ${ }^{47}, \mathrm{Kuhn}^{48}$ ). The fifth factor was labeled "Trust Issues in IT" (see Table 4-2, for examples, Gefen et al. ${ }^{49}$, and McKnight et al. ${ }^{50}$ ). The sixth factor was "Knowledge Management" (see Table 4-2, for examples, Robey et $\mathrm{al}^{51}$, Nonaka ${ }^{52}$ ). The seventh factor was "Measurement Issues in Research" and was similar to the case study issue in that it focuses on methodological issues in MIS study (see Table 4-2, for examples, Armstrong and Overton ${ }^{53}$, Anderson and Gerbing ${ }^{54}$ ). The eighth factor was "Diffusion of Innovation," and is about the role and sustained impact of IT in organizations (see Table 4-2, for examples, Cooper and Zmud $^{55}$, Tornatzky and Klein ${ }^{56}$ ). The ninth factor was "Success Factors of 
IT," as studies here were trying to build a holistic model for IS to succeed (see Table 4-2, for examples, DeLone and McLean ${ }^{57,58}$, and Melville et al. ${ }^{59}$ ). The tenth factor was "Research Modeling and Approach," covers some mixed topics about research; from approach ${ }^{60}$ to the way a construct is modeled ${ }^{61}$. The eleventh factor was "Theory, Research and Practice," and included papers introducing different theories and suggestion on how to bridge the gap between research and practice (see Table 4-2). The twelfth factor was "MIS as an academic discipline," and came with two papers discussing core identity and IT definition of the MIS field (see Table 4-2, for examples, Benbasat and Zmud ${ }^{62}$; Orlikowski and Iacono ${ }^{63}$ ). The thirteenth and last factor was "Enterprise Information Systems." These papers discussed the balance between system and organization ${ }^{64}$ and a combined subjectivity/objectivity view for looking into IT in organization ${ }^{65}$.

Table 4-2. Factor qnalysis

\begin{tabular}{|c|c|c|c|c|c|}
\hline Factor & Main Concept & Major source document & $\begin{array}{l}\text { Eigen } \\
\text { values }\end{array}$ & $\begin{array}{c}\text { Percent } \\
\text { of } \\
\text { variance } \\
\text { explained }\end{array}$ & $\begin{array}{c}\text { Sum of } \\
\text { Percent } \\
\text { of } \\
\text { variance } \\
\text { explained }\end{array}$ \\
\hline Factor 1 & $\begin{array}{l}\text { Technology } \\
\text { Acceptance }\end{array}$ & $\begin{array}{c}\text { Davis et al. (1989) } \\
\text { Venkatesh and Davis (2000) } \\
\text { Taylor and Todd (1995) } \\
\text { Goodhue and Thompson (1995) } \\
\text { Mayer et al. (1995) } \\
\text { Compeau and Higgins (1995) } \\
\text { Desanctis and Poole (1994) } \\
\text { Davis (1989) } \\
\text { Gefen and Straub (1997) } \\
\text { Venkatesh and Morris (2000) } \\
\text { Swanson (1994) } \\
\text { Straub et al. (1995) } \\
\text { Bailey and Pearson (1983) } \\
\text { Agarwal and Karahanna (2000) } \\
\text { Kogut and Zander (1992) } \\
\text { Mukhopadhyay et al. (1995) } \\
\text { Fornell and Larcker (1981) } \\
\text { Koufaris (2002) } \\
\text { Hevner et al. (2004) } \\
\text { Chin and Newsted (2003) } \\
\text { Gefen et al. (2000) } \\
\text { Barclay et al. (1995) } \\
\text { Chin (1998) } \\
\text { Podsakoff et al. (2003) } \\
\text { Straub (1989) } \\
\text { Venkatesh et al. (2003) }\end{array}$ & 29.348 & 24.871 & 24.871 \\
\hline
\end{tabular}


Table 4-2. Factor analysis (Cont.)

\begin{tabular}{|c|c|c|c|c|c|}
\hline Factor & Main Concept & Major source document & $\begin{array}{l}\text { Eigen } \\
\text { values }\end{array}$ & $\begin{array}{c}\text { Percent } \\
\text { of } \\
\text { variance } \\
\text { explained }\end{array}$ & $\begin{array}{c}\text { Sum of } \\
\text { Percent } \\
\text { of } \\
\text { variance } \\
\text { explained }\end{array}$ \\
\hline Factor 2 & $\begin{array}{c}\text { IT, } \\
\text { Organization } \\
\text { Performance, } \\
\text { and } \\
\text { Competitive } \\
\text { Advantage }\end{array}$ & $\begin{array}{c}\text { Alavi and Leidner (2001) } \\
\text { Bharadwaj (2000) } \\
\text { Markus et al. (1983) } \\
\text { Seddon (1997) } \\
\text { Armstrong and Sambamurthy (1999) } \\
\text { Orlikowski (2000) } \\
\text { Brynjolfsson and Hitt (1996) } \\
\text { Carr (2003) } \\
\text { Grant (1996) } \\
\text { Eisenhardt and Martin (2000) } \\
\text { Sambamurthy et al. (2003) } \\
\text { Hartwick and Barki (1994) } \\
\text { Adams et al. (1992) } \\
\text { Barua et al. (1995) } \\
\text { Porter and Millar (1985) } \\
\text { Podsakoff and Organ (1986) } \\
\text { Wernerfelt (1984) } \\
\text { Prahalad and Hamel (1990) } \\
\text { Iacovou et al. (1995) } \\
\text { Campbell and Fiske (1959) }\end{array}$ & 20.285 & 17.191 & 42.062 \\
\hline Factor 3 & $\begin{array}{c}\text { IT and } \\
\text { Organizational } \\
\text { Structure }\end{array}$ & $\begin{array}{c}\text { Markus and Robey (1988) } \\
\text { Orlikowski (1992) } \\
\text { Grant (1996) } \\
\text { DiMaggio and Powell (1983) } \\
\text { Malone et al. (1987) } \\
\text { Orlikowski (1996) } \\
\text { Mata et al. (1995) } \\
\text { Robey et al. (1999) } \\
\text { Curtis et al. (1988) } \\
\text { Powell and DentMicallef (1997) }\end{array}$ & 13.017 & 11.032 & 53.094 \\
\hline Factor 4 & $\begin{array}{l}\text { Case Study } \\
\text { and } \\
\text { Methodology } \\
\text { Issues }\end{array}$ & $\begin{array}{c}\text { Moore and Benbasat (1991) } \\
\text { Lee (1989) } \\
\text { Jarvenpaa and Leidner (1999) } \\
\text { Walsham (1995) } \\
\text { Eisenhardt (1989) } \\
\text { Benbasat et al. (1987) } \\
\text { Daft and Lengel (1986) } \\
\text { Lyytinen (1987) } \\
\text { Nunamaker et al.(1991) }\end{array}$ & 6.391 & 5.416 & 58.510 \\
\hline Factor 5 & $\begin{array}{c}\text { Trust issues in } \\
\text { IT }\end{array}$ & $\begin{array}{c}\text { Mathieson (1991) } \\
\text { Ba and Pavlou (2002) } \\
\text { Majchrzak et al. (2000) } \\
\text { Baron and Kenny (1986) } \\
\text { McKnight et al. (2002) } \\
\text { Gefen et al. (2003) }\end{array}$ & 5.299 & 4.491 & 63.000 \\
\hline
\end{tabular}


Table 4-2. Factor analysis (Cont.)

\begin{tabular}{|c|c|c|c|c|c|}
\hline Factor & Main Concept & Major source document & $\begin{array}{l}\text { Eigen } \\
\text { values }\end{array}$ & $\begin{array}{l}\text { Percent } \\
\text { of } \\
\text { variance } \\
\text { explained }\end{array}$ & $\begin{array}{c}\text { Sum of } \\
\text { Percent } \\
\text { of } \\
\text { variance } \\
\text { explained }\end{array}$ \\
\hline Factor 6 & $\begin{array}{l}\text { Knowledge } \\
\text { Management }\end{array}$ & $\begin{array}{c}\text { Nonaka (1994) } \\
\text { Karahanna et al. (1999) } \\
\text { Robey et al. (2002) } \\
\text { Attewell (1992) } \\
\text { Clemons et al. (1993) } \\
\text { Lee (1991) } \\
\text { Cohen and Levinthal (1990) }\end{array}$ & 4.747 & 4.023 & 67.023 \\
\hline Factor 7 & $\begin{array}{l}\text { Measurement } \\
\text { Issues in } \\
\text { Research }\end{array}$ & $\begin{array}{c}\text { Bagozzi et al. (1991) } \\
\text { Churchill (1979) } \\
\text { Earl (1993) } \\
\text { Armstrong and Overton (1977) } \\
\text { Teece et al. (1997) } \\
\text { Anderson et al. (1988) } \\
\text { Venkatesh (2000) }\end{array}$ & 3.958 & 3.355 & 70.378 \\
\hline Factor 8 & $\begin{array}{l}\text { Diffusion of } \\
\text { Innovation }\end{array}$ & $\begin{array}{c}\text { Ross et al. (1996) } \\
\text { Orlikowski and Gash (1994) } \\
\text { Cooper and Zmud (1990) } \\
\text { Hirschheim and Klein (1989) } \\
\text { Tornatzky and Klein (1982) }\end{array}$ & 3.684 & 3.122 & 73.500 \\
\hline Factor 9 & $\begin{array}{l}\text { Success Factor } \\
\text { of IT }\end{array}$ & $\begin{array}{l}\text { Brown and Duguid (1991) } \\
\text { Melville et al. (2004) } \\
\text { DeLone and McLean (2003) } \\
\text { DeLoneabd McLean (1992) }\end{array}$ & 3.052 & 2.587 & 76.086 \\
\hline Factor 10 & $\begin{array}{l}\text { Research } \\
\text { Modeling and } \\
\text { Approach }\end{array}$ & $\begin{array}{l}\text { Orlikowski and Baroudi (1991) } \\
\text { Ives et al. (1983) } \\
\text { Lacity and Willcocks (1998) } \\
\text { Jarvis et al. (2003) }\end{array}$ & 2.623 & 2.223 & 78.309 \\
\hline Factor 11 & $\begin{array}{l}\text { Theory, } \\
\text { Research and } \\
\text { Practice }\end{array}$ & $\begin{array}{c}\text { Wade and Hulland (2004) } \\
\text { Orlikowski (1993) } \\
\text { Ngwenyama and Lee (1997) } \\
\text { Benbasat and Zmud (1999) }\end{array}$ & 2.361 & 2.001 & 80.309 \\
\hline Factor 12 & $\begin{array}{l}\text { MIS as an } \\
\text { academic } \\
\text { discipline }\end{array}$ & $\begin{array}{c}\text { Mcknight et al. (1998) } \\
\text { Benbasat and Zmud (2003) } \\
\text { Orlikowski and Iacono (2001) } \\
\text { Ajzen (1991) }\end{array}$ & 1.983 & 1.681 & 81.990 \\
\hline Factor 13 & $\begin{array}{l}\text { Enterprise } \\
\text { Information } \\
\text { Systems }\end{array}$ & $\begin{array}{c}\text { Davenport (1998) } \\
\text { Orlikowski and Robey (1991) }\end{array}$ & 1.819 & 1.542 & 83.532 \\
\hline
\end{tabular}

\section{CONCLUSION}

Firms have been using information technology to improving daily operations and to gain a competitive advantage since the early days of computers. However, it is crucial to understand both the virtues and limitations of IT, especially in a timely manner. Key issues in MIS, such as those provided in this study, serve as a map to help businesses grasp current developments and the distribution of issues being researched within 
academia. With this knowledge, firms are better able to allocate resources to leverage IT.

The key issues that are being given attention require regular updates. This paper shows that thirteen key issues were found in current academic periodicals, including (1) Technology Acceptance; (2) IT, Organization Performance, and Competitive Advantage; (3) IT and Organizational Structure; (4) Case Study and Methodology Issues; (5) Trust Issues in IT; (6) Knowledge Management; (7) Measurement Issues in MIS study; (8) Diffusion of Innovation; (9) Success Factors of IT; (10) Research Modeling and Approach; (11) Theory, Research and Practice; (12) MIS as an academic discipline; and (13) Enterprise Information Systems.

The main contributions of this study include: (1) For academics, highly-cited papers and co-citation analysis focused on the MIS field, allowing researchers to follow and direct effort to current key topics of research; and (2) For practitioners, key issues help business to stay current on development in IT strategy and planning. As technology is fast advancing and changing, it is hoped that this study would be helpful for both academia and the business world.

\section{REFERENCES}

[1] G.W. Dickson, R.L. Leitheiser, J.C. Wetherbe, and M. Nechis, Key information systems issues for the 1980's. MIS Quarterly, 8(3), p135-159, 1984. http://dx.doi.org/10.2307/248662.

[2] M.E. Porter, and V.E. Millar, How information gives you competitive advantage. Harvard Business Review, 63(4), p149-160, 1985.

[3] L.D. Ball, and R.G.H. Harris, SMIS members: A membership analysis. MIS Quarterly, 6(1), p19-38, 1982. http://dx.doi.org/10.2307/248752.

[4] F. Niederman, J.C. Brancheu, and J.C. Wetherbe, Information systems management issues for the 1990s. MIS Quarterly, 15(4), p475-500, 1991. http://dx.doi.org/10.2307/249452.

[5] P.C. Palvia, B. Rajagopalan, A. Kumar, and N. Kumar, Key information systems issues: An analysis of MIS publications. Information Processing \& Management, 32(3), p345-355, 1996. http://dx.doi.org/10.1016/0306-4573(95)00056-9.

[6] J. Luftman, and R. Kempaiah, Key issues for IT executives 2007. MIS Quarterly Executive, 7(2), p99-112, 2008.

[7] J. Luftman, and T. Ben-Zvi, Key issues for IT Executives 2009: Difficult economy's impact on IT. MIS Quarterly Executive, 9(1), p203-213, 2010.

[8] H. Small, Co-citation in the scientific literature: A new measure of the relationship between two documents. Journal of the American Society 
for Information Science, 24(4), p265-269, 1973. http://dx.doi.org/10.1002/asi.4630240406.

[9] M.M. Kessler, Bibliographic coupling between scientific papers. American Documentation, 14(1), p10-25, 1963. http://dx.doi.org/10.1002/asi.5090140103.

[10] M.J. Culnan, Mapping the intellectual structure of MIS, 1980-1985: A co-citation analysis. MIS Quarterly, 11(3), p341-353, 1987.

[11] J. Locke, and H. Perera, The intellectual structure of international accounting in the early 1990s. The International Journal of Accounting, $36(2)$, p223-249,

2001. http://dx.doi.org/10.1016/S0020-7063(01)00095-4.

[12] H.D. White, and B.C. Griffith, Author cocitation: A literature measure of intellectual structure. Journal of the American Society for Information Science, 32(3), p163-171, 1981. http://dx.doi.org/10.1002/asi.4630320302.

[13] K.W. McCain, Mapping economics through the journal literature: An experiment in journal cocitation analysis. Journal of the American Society for Information Science, 42(4), p290-296, 1991. http://dx.doi.org/10.1002/(SICI)1097-4571(199105)42:4\%3C290::AID -ASI5\%3E3.0.CO;2-9.

[14] H.A. Schildt, S.A. Zahra, and A. Sillanpää, Scholarly communities in entrepreneurship research: A co-citation analysis. Entrepreneurship Theory and Practice, 30(3), p399-415, 2006. http://dx.doi.org/10.1111/j.1540-6520.2006.00126.x.

[15] M. Tight, Higher education research as tribe, territory and/or community: A co-citation analysis. Higher Education, 55(5), p593-605, 2008. http://dx.doi.org/10.1007/s10734-007-9077-1.

[16] A. Pilkington, and J. Meredith, The evolution of the intellectual structure of operations management-1980-2006: A citation/co-citation analysis. Journal of Operations Management, 27(3), p185-202, 2009. http://dx.doi.org/10.1016/j.jom.2008.08.001.

[17] X. Lin, H.D. White, and J. Buzydlowski, Real-time author co-citation mapping for online searching. Information Processing \& Management, 39(5), p689-706, 2003. http://dx.doi.org/10.1016/S0306-4573(02)00037-7.

[18] C.H. Hsiao, and C. Yang, The intellectual development of the technology acceptance model: A co-citation analysis. International Journal of Information Management, 31(2), p128-136, 2011. http://dx.doi.org/10.1016/j.ijinfomgt.2010.07.003.

[19] A. Pritchard, Statistical bibliography or bibliometrics. Journal of Documentation, 25(4), p348-349, 1969.

[20] L.C. Smith, Citation analysis. Library Trends, 30(1), p83-106, 1981. 
[21] D.J. Price, Networks of scientific papers. Science, 149(3683), p510-515, 1965. http://dx.doi.org/10.1126/science.149.3683.510.

[22] H. Small, and B.C. Griffith, The structure of scientific literatures I: Identifying and graphing specialties. Science Studies, 4(1), p17-40, 1974. http://dx.doi.org/10.1177/030631277400400102.

[23] K.W. McCain, Mapping authors in intellectual space: A technical overview. Journal of the American Society for Information Science, 41(6), p433-443, 1990. http://dx.doi.org/10.1002/(SICI)1097-4571(199009)41:6\%3C433::AID -ASI11\%3E3.0.CO;2-Q.

[24] Members of the Senior Scholars Consortium, Senior scholars' basket of journals. Retrieved on November 17, 2011, from http://aisnet.org/?SeniorScholarBasket.

[25] H.D. White, Pathfinder networks and author cocitation analysis: A remapping of paradigmatic information scientists. Journal of the American Society for Information Science, 54(5), p423-434, 2003. http://dx.doi.org/10.1002/asi.10228.

[26] H. Small, Paradigms, citations, and maps of science: A personal history. Journal of the American Society for Information Science and Technology, 54(5), p394-399, 2003. http://dx.doi.org/10.1002/asi.10225.

[27] V. Venkatesh, and F.D. Davis, A theoretical extension of the technology acceptance model: Four longitudinal field studies. Management Science, 46(2), p186-204, 2000. http://dx.doi.org/10.1287/mnsc.46.2.186.11926.

[28] D. Straub, and M. Limayen, Measuring system usage: Implications for IS theory testing. Management Science, 41(8), p1328-1343, 1995. http://dx.doi.org/10.1287/mnsc.41.8.1328.

[29] J.E. Bailey, and S.W. Pearson, Development of a tool for measuring and analyzing computer user satisfaction. Management Science, 29(5), p530-545, 1983. http://dx.doi.org/10.1287/mnsc.29.5.530.

[30] R.C. Mayer, J.H. Davis, and F.D. Schoorman, An integrative model of organizational trust. The Academy of Management Review, 20(3), p709-734, 1995. http://dx.doi.org/10.2307/258792.

[31] W.W. Chin, B.L. Marcolin, and P.R. Newsted, A partial least squares latent variable modeling approach for measuring interaction effects: Results from a monte carlo simulation study and an electronic-mail emotion/adoption study. Information Systems Research, 14(2), p189-217, 2003. http://dx.doi.org/10.1287/isre.14.2.189.16018.

[32] G. DeSanctis, and M.S. Poole, Capturing the complexity in advanced technology use: Adaptive structuration theory. Organization Science, 5(2), p121-147, 1994. http://dx.doi.org/10.1287/orsc.5.2.121. 
[33] F.D. Davis, A technology acceptance model for empirically testing new end-user information systems: theory and results, Massachusetts Institute of Technology. Retrieved on November 17, 2011, from http://hdl.handle.net/1721.1/15192.

[34] E. Karahanna, D.W. Straub, and N.L. Chervany, Information technology adoption across time: A cross-sectional comparison of pre-adoption and post-adoption beliefs. MIS Quarterly, 23(2), p183-213, 1999.

[35] V. Venkatesh, Determinants of perceived ease of use: Integrating control, intrinsic motivation, and emotion into the technology acceptance model. Information Systems Research, 11(4), p342-365, 2000. http://dx.doi.org/10.1287/isre.11.4.342.11872.

[36] V. Venkatesh, M.G. Morris, G.B. Davis, and F.D. Davis, User acceptance of information technology: Toward a unified view. MIS Quarterly, 27(3), p425-478, 2003.

[37] A.S. Bharadwaj, A resource-based perspective on information technology capability and firm performance: An empirical investigation. MIS Quarterly, 24(1), p169-196, 2000. http://dx.doi.org/10.2307/3250983.

[38] N.G. Carr, IT doesn't matter. Harvard Business Review, 81(5), p41-49, 2003.

[39] A. Barua, C.H. Kriebel, and T. Mukhopadhyay, Information technologies and business value: An analytic and empirical investigation. Information Systems Research, 6(1), p3-23, 1995. http://dx.doi.org/10.1287/isre.6.1.3.

[40] W.J. Orlikowski, Using technology and constituting structures: A practice lens for studying technology in organizations. Organization Science, $\quad 11(4), \quad$ p404-428, 2000. http://dx.doi.org/10.1287/orsc.11.4.404.14600.

[41] R.M. Grant, Toward a knowledge-based theory of the firm. Strategic Management Journal, 17(S2), p109-122, 1996. http://dx.doi.org/10.1002/smj.4250171110.

[42] M.L. Markus, Power, politics, and MIS implementation. Communications of the ACM, 26(6), p430-444, 1983. http://dx.doi.org/10.1145/358141.358148.

[43] W.J. Orlikowski, The duality of technology: Rethinking the concept of technology in organizations. Organization Science, 3(3), p398-427, 1992. http://dx.doi.org/10.1287/orsc.3.3.398.

[44] D. Robey, and M.-C. Boudreau, Accounting for the contradictory organizational consequences of information technology: Theoretical directions and methodological implications. Information Systems Research, 10(2), p167-185, 1999. http://dx.doi.org/10.1287/isre.10.2.167. 
[45] W.J. Orlikowski, Improvising organizational transformation overtime: A situated change perspective. Information Systems Research, 7(1), p63-92, 1996. http://dx.doi.org/10.1287/isre.7.1.63.

[46] A.S. Lee, A scientific methodology for MIS case studies. MIS Quarterly, 13(1), p33-50, 1989. http://dx.doi.org/10.2307/248698.

[47] G. Walsham, Interpretive case studies in IS research: Nature and method. European Journal of Information Systems, 4, p74-81, 1995. http://dx.doi.org/10.1057/ejis.1995.9.

[48] T.S. Kuhn, The structure of scientific revolutions. Chicago, IL: University of Chicago Press, 1962.

[49] D. Gefen, E. Karahanna, and D.W. Straub, Trust and TAM in online shopping: An integrated model. MIS Quarterly, 27(1), p51-90, 2003.

[50] D.H. McKnight, V. Choudhury, and C. Kacmar, Developing and validating trust measures for e-commerce: An integrative typology. Information Systems Research, 13(3), p334-359, 2002. http://dx.doi.org/10.1287/isre.13.3.334.81.

[51] D. Robey, J.W. Ross, and M.-C. Boudreau, Learning to implement enterprise systems: An exploratory study of the dialectics of change. Journal of Management Information Systems, 19(1), p17-46, 2002.

[52] Nonaka, A dynamic theory of organizational knowledge creation. $\begin{array}{llll}\text { Organization } & \text { Science, } & \text { 5(1), } & \text { p14-37, }\end{array}$ http://dx.doi.org/10.1287/orsc.5.1.14.

[53] J.S. Armstrong, and T.S. Overton, Estimating nonresponse bias in mail survey. Journal of Marketing Research, 14(3), p396-402, 1977. http://dx.doi.org/10.2307/3150783.

[54] J.C. Anderson, and D.W. Gerbing, Structural equation modeling in practice: A review and recommended two-step approach. Psychological Bulletin, 103(3), p411-423, 1988. http://dx.doi.org/10.1037/0033-2909.103.3.411.

[55] R.B. Cooper, and R.W. Zmud, Information technology implementation research: A technological diffusion approach. Management Science, 36(2), p123-139, 1990. http://dx.doi.org/10.1287/mnsc.36.2.123.

[56] L.G. Tornatzky, and K.J. Klein, Innovation characteristics and innovation adoption-implementation: A meta-analysis of findings. IEEE Transactions on Engineering Management, 29(1), p28-43, 1982. http://dx.doi.org/10.1109/TEM.1982.6447463.

[57] W.H. DeLone, and E.R. McLean, Information systems success: The quest for the dependent variable. Information Systems Research, 3(1), p60-95, 1992. http://dx.doi.org/10.1287/isre.3.1.60.

[58] W.H. Delone, and E.R. McLean, The DeLone and McLean model of information systems success: A ten-year update. Journal of Management Information Systems, 19(4), p9-30, 2003. 
[59] N. Melville, K. Kraemer, and V. Gurbaxani, Review: Information technology and organizational performance: An integrative model of IT business value. MIS Quarterly, 28(2), p283-322, 2004.

[60] W.J. Orlikowski, and J.J. Baroudi, Studying information technology in organizations: Research approaches and assumptions. Information $\begin{array}{llll}\text { Systems } & \text { Research, 2(1), p1-28, } & 1991 .\end{array}$ http://dx.doi.org/10.1287/isre.2.1.1.

[61] C.B. Jarvis, S.B. Mackenzie, P.M. Podsakoff, D.G. Mick, and W.O. Bearden, A critical review of construct indicators and measurement model misspecification in marketing and consumer research. Journal of Consumer Research, 30(2), p199-218, 2003. http://dx.doi.org/10.1086/376806.

[62] Benbasat, and R.W. Zmud, The identity crisis within the IS discipline: Defining and communicating the discipline's core properties. MIS Quarterly, 27(2), p183-194, 2003.

[63] W.J. Orlikowski, and C.S. Iacono, Research commentary: Desperately seeking 'IT' in IT research - A call to theorizing the IT artifact. Information Systems Research, 12(2), p121-134, 2001. http:/dx.doi.org/10.1287/isre.12.2.121.9700.

[64] T.H. Davenport, Putting the enterprise into the enterprise system. Harvard Business Review, 76(4), p121-131, 1998.

[65] W.J. Orlikowski, and D. Robey, Information technology and the structuring of organizations. Information Systems Research, 2(2), p143-169, 1991. http://dx.doi.org/10.1287/isre.2.2.143. 